\title{
Participation in Student's Union: An Agenda for Discussions on Gender Issues, Citizenship and Didactics
}

\author{
Tânia Antonelli Marcelino Brabo, Rosane Michelli de Castro², Alexandre de Castro ${ }^{3}$
}

${ }^{1}$ Department of School Administration and Supervision at the Program of Postgraduate on Education in the Faculty of Philosophy and Sciences (FFC)-UNESP, Marília, Brazil

${ }^{2}$ Department of Didactics and at the Program of Postgraduate on Education in the Faculty of Philosophy and Sciences (FFC)UNESP, Marília, Brazil

${ }^{3}$ Social Sciences courses in the State University of Mato Grosso do Sul/Paranaíba, Mato Grosso do Sul, Brazil

Email: tamb@terra.com.br, rosanemichelli@marilia.unesp.br, xadrecas@gmail.com

How to cite this paper: Brabo, T. A. M., de Castro, R. M., \& de Castro, A. (2017). Participation in Student's Union: An Agenda for Discussions on Gender Issues, Citizenship and Didactics. Creative Education, 8, 942952.

https://doi.org/10.4236/ce.2017.86069

Received: September 4, 2016

Accepted: May 28, 2017

Published: May 31, 2017

Copyright (c) 2017 by authors and Scientific Research Publishing Inc. This work is licensed under the Creative Commons Attribution International License (CC BY 4.0).

http://creativecommons.org/licenses/by/4.0/

\section{Abstract}

This work is a due to a case study conducted in three schools, two public elementary and high school and in a Educational Cooperative, in two medium-sized cities of São Paulo, Brazil, and of our actions in the field of didactics. It aimed to understand the importance of participation of pupils and students in Student's Unions, for discussion agenda of motivation on gender issues, citizenship and didactics. It was developed along the lines of a qualitative research, by observing the meetings, the electoral process and the actions they undertake in schools, interviews with its members, in addition to analyzing the various school plans. The literature on the subject shows that the student movements were predominantly university movements and that the students, especially high school students, always have been seen as a threat to educational institutions, and rarely as subjects, men in women in formation, required for projects of school and to citizenship. In general, the student participation bothered and was curtailed by educational administrators even in times when legislation and educational policies encouraged. It was observed that there is interest on the part of students to participate, whether boys or girls. Meetings are moments of dialogue among all without distinction of sex. The election campaign, from the preparation of the work proposals to the presentation of it to set off the two school communities, constitutes it like important moments of learning and incorporation of a democratic culture. In schools, most members of the Unions was composed of young men; however, it was found that there has been a growing interest in girls of assuming the presidency of this organization. In the educational cooperative, at the time of the survey, although there were school director's interests for the creation of 
the Union, it was not possible to achieve necessary motivation not even students for the creation of the organization. The depositions showed that political participation through the Student's Unions constitutes an important element for democratic learning, for participation in school projects, centrally at all stages of the political pedagogical project, and exercise of the citizenship for both sexes.

\section{Keywords}

Education, Gender, Didactics, Citizenship, Democracy, Student's Unions, Pedagogical Political Project

\section{Introduction}

Almost twenty years after the promulgation of the Constitution of the Federative Republic of Brazil, in 1988, that have like principles of democracy and which includes social rights, civil and political, it appears that Brazil's return to democracy did not allow all men and women, the full access to citizenship, participation in public space. Social scientists see as the cause of difficulties for political practice the fact that, historically, the constituent rights of citizenship were not conquered by political struggles, but granted by an anti-liberal state in a hierarchical society by slavery. This process of constitution of citizenship would have prevented the formation of a civic culture and a sense of democratic citizenship among Brazilians.

As affirm Ferreira (2004), in a study which analyzed the political citizenship of young people in several countries in Europe, the need for the formation of "real citizens" became the education for citizenship, a central issue in the political agenda of European societies, because the participation is necessary for the development of democracy. In Brazil, we can say that this need was also felt making active citizenship passed to be seen as a necessity, as set out in Benevides (1994). However, in 2007, after more than ten years after the promulgation of the Law of Guidelines and Bases of National Education, it has yet to materialize the ideal of education and democratic school.

Aside from the historical factors, there which be noted if in the schools are forming young for full citizenship and that assimilate democratic values. Furthermore, there which be observed if and how the participation, democracy assumption in society beyond the school occurs. This concern is also present in theory, as Ferreira (2004, p.1, our translation) is observed that in democratic societies had happened a crisis of democratic representation, expressed in the "decline of identification of citizens with the functioning of political institutions, which is manifested in weak party membership, emptying the ideological fractures or debility of electoral participation [...]". The author also noted that in countries where there are a greater guarantee of rights and confidence in democracy, political participation in all its forms, is higher; precisely those in which there is greater need for civil society exercise the political and social citi- 
zenship, as in the case of Portugal, this share is lower.

In research conducted in a medium-sized school in the state of São Paulo, Brazil, in 2000, we observed that there was, by the electorate, a disenchantment with politics, ignorance and distance of the majority of the organs of civil society participation (rights councils, trade unions, political parties, school councils, among others) (Brabo, 2003). When participation occurs, for example, the municipal rights councils often occur, it has been found in School Councils. The political arena, apart from the times of elections, seems to be far from the majority of the population.

Considering the insertion and action of the subjects in training in schools, boys and girls, we observed that their participation centrally in the larger document of the school, its political-pedagogical project, could only be thought of if it were woven in the collective of the school community: focusing on the learner; considering the school insertion context; favoring the creation of study and reflection and interfering in the general articulation of the curriculum, and finally, requiring teachers and other professionals working in school knowledge and know how to do.

These issues motivated the research whose results presented here, because if the participation is a prerequisite for the development of democracy, there which be verify how the school is forming the citizen and the political citizen, especially students members of the Union of Student. In this text, we will cover in the first topic, results of actions and reflections made in one of the schools surveyed about the importance of participation of all subjects and school boards, so the school plans, centrally their political pedagogical project is the result the active participation of all subjects of the school, including students in formation for citizenship. In the following topics, we set out the findings of qualitative research developed in two primary and secondary schools of Marilia (SP), a state and an educational cooperative, by observing the performance of this organ in schools and meetings, proposal analysis work and monitoring the electoral process. Its central objective is to present elements that can contribute to the reflection on the issues: how the school has made to political citizenship, as is the participation of/the young people in Student's Unions and school and social gender relations in that organization.

\section{Reflections in the Field of Didactics for Effective Participation of Male and Female Students in School: The Construction Process of the Political-Pedagogical Project in Focus}

Whatever the discussions and reflections on the formation of students in schools for effective participation in social processes, therefore, for citizenship, the reflections on didactics will be, inevitably, implicitly or explicitly, for taking a political and theoretical position in all educational and administrative actions of the school. Such an idea would have opened space for important discussions that would have expanded the view of didactics, in the 1980s, than, including, con- 
substantiated alternative proposals for didactics in Brazil since then.

Within these discussions, one of the themes that strongly recognizes this role or function of the didactics, of search for a theoretical, political-pedagogical position, is certainty, the issue in question "The construction of the education program at school."

Regarding the title and the idea of this topic, we allow ourselves to formulate them based on an experience for us guidance for the preparation of the political pedagogical project of a public school in a medium-sized city of São Paulo, Brazil. $^{1}$

It was a (Programa de Educação Continuada) Continuing Education Program, of the (Secretaria Estadual da Educação do Estado de São Paulo) State Department of the São Paulo State Education along with UNESP/FUNDUNESP, developed in 1998.

Our major concern with this work was to work with all the subjects of the "school community" the idea that the construction route of the school project, was up at the school and through the effective participation of all subjects that community, driven by own needs and utopias, whose satisfaction of the latter would be subject to the means and processes also the community. And all this would be materialized discursively in a systematic way and planned, in the shape of a project, that nothing be lost along the way.

Hence, the first definition crafted with all the subjects, was the pedagogical project, understood as Vasconcelos (1999: 169), as systematization, not final, a participatory planning process that is improved and is concretized in walk that clearly defines the type of educational activities that want to accomplish. Still, the Educational Project of the School could be defined as "[...] a theoretical and methodological tool for intervention and change of reality" (Vasconcelos, 1999: 169 , our translation), whose effectiveness would be due to the collective participation of community subjects school, the construction of this instrument, which, ultimately, was the result of the construction of knowledge about the school itself.

A first exercise of participation occurred through the development of a group dynamic, "Your journey, your boat ...", in which participants were led to reflect on:

- cotidiano da sua escola e sobre as escolas atualmente;

- as dificuldades e possibilidades de superação dessas dificuldades;

- e, o papel pessoal de cada um em trabalho futuro para a superação das dificuldades encontradas.

After such dynamics, the importance of the participation of each was again highlighted, but now in the light of the Brazilian educational context, centrally, from the 1990s. This decade was remembered for being impregnated by the education decentralization talks, in response to the crisis of State's legitimacy, the school became valued as a local organization of workers that there should build its identity, and therefore, should work more with the plurality than equal-

${ }^{1}$ Such activity occurred as a result of the course taught by us, called "Building the identity of the School". 
ity, more with meaning than with the specific content, and very clearly on the issue of culture and local government in its relations with the global, and in the end, this new school will have to provide reflection and the consequent action by all those involved, after collective decision to reflect and act in favor of a thinking school in organization situations, activities and environments mediators of the teaching that generates learning. Given this situation, it has imposed the need:

- An education project to translate the about education school conceptions of the human person which is intended to form, the guiding values of society;

- A management project to give effect to such conceptions, creating conditions for the teaching happens in the school routine.

In this perspective, the pedagogical project could only be thought of if it were woven in the collective of the school community: focusing on the student; considering the school insertion context; favoring the creation of study and reflection and interfering in the general articulation of the curriculum, and finally, requiring teachers and other professionals working in school knowledge and know-how.

Subsequently, discussions were based on the primary characteristics of an educational project:

- Theoretical Rigor: have a conscious, effective in reflected form, systematized, organic, scientific, and what is essential, participatory;

- Ethics: The educational project has to be an effective transformation tool, which expresses the commitment of the group to walk;

- Autonomy: The educational project has to be a free instrument of action, but conscious, and if necessary, even to denounce situations and omissions of the State.

Synthetically, we now present possible steps to the process of development and implementation of the education program:

1) Emergence of the need for the project;

2) Working awareness and preparedness of the subjects;

3) Making collective decision;

4) Elaboration

- Reference Marco: What do we achieve? (It is the search for a political position - ideal vision of society and man, and teaching - definition of the educational action and the characteristics that must have the institution plans;

- Diagnosis: What we need to be what we want?

- Programming: What do we do concretely to address such failure? (Proposals for action).

5) Publication;

6) Interactive Realization;

7) Ongoing evaluation-Continuous update of the diagnosis;

8) Reprogrammation.

Finally, and focusing attention on assessment, care to say strongly that on the pedagogical project the critical gaze of the subjects should be released continuously, pointing alternative improvements for all those who "wear the same 
shirt," identifying the weak or dead spots, to them what's positive.

\section{Gender and Participation in the Democratic Brazil}

The problem of unequal participation of both sexes in political decision-making bodies has gained relevance and growing presence in the political debate of democratic countries,

In Brazil, particularly from the 1980s, political democracy was restored and then, in the 1990s, active citizenship has become the goal. This concern was also given in theory. Among the authors who show the citizen participation as one of the possibilities to restore the sense of politics and to restore the links between the institutions, individuals, classes and groups at local level, Reston (1990: 124, our translation) argues what

"[...] The municipality ends up becoming the most appropriate arena for the exercise of democratic practices: on the one hand, the citizen directly demanding the fulfillment of their needs; on the other hand, the municipality requiring the citizen to practice their civil responsibilities. [...] It is in the city, after all, the entity through which the citizen sees clearly the government presence because converge to the municipality the affairs of his immediate interest, waiting for an answer, realistic solutions to the problems."

In some democratic societies, such as the brazilian, the decentralization of public administration is an ongoing process in state reforms in recent decades. It happens that such changes, to be positive, providing a state of municipal Social Welfare, presuppose the organizational skills and participation of civil society with the government. However, it is noteworthy that the exercise of citizenship is difficult also, in Brazil, for historical and political factors and do not have a culture of participation, despite the democratic restoration.

The social movements, including the women, played an important role in the path that gave rise to the citizen and the citizen, the right to be subject to rights. In Brazil, authoritarian and conservative society, where historically ruled the privilege of the ruling classes for minorities has always been difficult to reach the public space to claim their rights and be heard. Historically, any manifestation of release had been eliminated by violence and repression (Paoli, 1995). Our citizenship has always been more passive than active. Sales (1994) points out the roots of social inequality in Brazilian politics, drawing a picture of the construction of citizenship; to the author we have a "citizenship granted", which was not conquered. Historically, instead of working the notion of rights, the culture was cultivated the "gift".

This makes us reflect on the ways of democracy in Brazil, from the 1980s until today, since according to Bobbio (1987: 55, our translation) the predominant meaning of democracy is "[...] a set of rules (so-called game rules) which allow the widest and safe participation of the majority of citizens, directly or indirectly, in the decisions that affect the whole community".

To discuss ways of evaluating how much a society is democratic, Bobbio 
(1989) makes mention of what defines as social democracy, saying that, in addition to know about how they vote, you need to know where there are guaranteed places to practice your right to voice and vote. Thus, in the case of the democratization process we can say that "it is not as much [...] in the transition from representative democracy to direct democracy as the passage of political democracy in its strict sense to social democracy.) (Bobbio 1987: 54, our translation). Thus, a more democratic country would be one in which the mechanisms of participation - direct or representative, were varied. In this sense, social democracy refers to the possibility that all citizens have real conditions to be heard by participating in all levels of decision making that somehow affect your life. The underlying idea here is related to the importance of the state itself control by the citizen and citizen, in its various forms of action or any service provided by it, such as education or health, for example.

We share in this brief analysis, the thought of authors who have dedicated themselves to understand why the difficulty of participation of men and women in addition to the unfair situation of women in society, in the exercise of democracy. There is consensus that women as well as other stakeholders, have their rights guaranteed from a practical point of view and, in addition, there remain high levels of social inequality in Brazil. Political representation in liberal democracies remains an area of difficult access to a set of social actors who have been historically denied citizenship. For these reasons, democracy has become the subject of studies that try to understand and/or explain the current society.

\section{Education, Participation e Gender: Politics e Practices}

The stimulus and promotion of participation constitutes a duty of both the school administration and faculty, expressed in the Lei de Diretrizes e Bases (Guidelines and Framework Act), in 1996. However, in spite of democracy, participation and formation for citizenship appear policies educational, its effectiveness is still an ideal to be achieved.

In addition to working the democratic values and gender across the board in the curriculum, as proposed the Parâmetros Curriculares Nacionais (National Curriculum Parameters) (Brazil, 1997), the school should encourage and support the work of young people in Student's Union, since this organization can be a democratic participation of learning locus. Thus, there will be possibility of developing a culture of participation, assumption of democratic management and necessity in a globalized society.

In São Paulo, Brazil, in the 1980s, consistent with the yearning of democratization of the country, the Government Montoro proposed a democratic educational policy with an investment in the collective bodies of school (in the Councils, the Association of Parents and Teachers, Unions of Student), to the development of democratic participation practices and the construction of citizenship, both faculty as the student and the community at school. With regard to education, Pedagogical Proposals for Elementary Education (São Paulo, 1992)

${ }^{2}$ Source: DEBATE- Women and education: the role of women in society. SEE-ATPCE, SP 1987. 
brought changes in order to form for citizenship.

It turns out that there was, at that time, resistance to this new way to teach and administer. The democratization process underway in society in general, apparently did not occur at school. During that time the ssessoria Técnica de Planejamento e Controle Educacional ${ }^{2}$ (Technical Assistance of Educational Planning and Control)_ATPCE (São Paulo, 1987), proposed discussing, in all schools in São Paulo the woman question, the starting point for a larger project, which was not continued. ${ }^{3}$

With regard to the Student's Unions, in 1980, with the enactment of Federal Law n. 7398/1985, the student movement is resumed and Alumni are encouraged by the Secretária da Educação (Department of Education) - SE, which promoted several meetings to discuss the formation and function of the institution at school. However, according to Pescuma (1990), the Congress promoted by SE excluded the Municipal Union of Secondary Students (SKUs), the São Paulo Union of Secondary Students (UPES) and the Brazilian Union of Secondary Students (UBEs). Aredes (2002) states that there was a certain fear in relation to these entities believed that college students or high school were a threat to the established power.

In the 1990s, nationwide, reaffirms the need for training for active citizenship and public school has undergone new changes, with the enactment of the Law of Guidelines and Bases of National Education in 1996 (Cury, 2000) and adoption of the National Curriculum Parameters (Brazil, 1997), in which democracy, citizenship and the gender issue is contemplated, from this moment, for the whole country. In São Paulo, democratic management is reaffirmed in the state educational legislation, including the Statutory Rules Basic (São Paulo State, 1998).

In previous work, undertaken in the period 1994-1997, which had as its object of study this state school, it was found that gender issues were part of the imagination of teachers, but not of their teaching practice. Until that moment, in 1997, not observed any educational gender policy and no change in this reality that school unit, except it is 1986, when occurred the aforementioned debate, the Paulistas state schools on the role of women in society (Brabo, 2005).

As Oliveira (2001: 31, our translation), the democratizing political action will take place inside the school in the transformation of interpersonal relationships that occur in their daily lives, through the expansion of opportunities for participation in debates respecting the differences of interest between the many individuals and groups interact, "and creating conditions for an autonomous participation of the various segments, enabling, in this process, the flattening of the power relations between them."

In legal terms, the Normas Regimentais Básicas para as Escolas Estaduais (Statutory Rules Basic for state schools) - NRB, formulated in the light of Law and Basic Guidelines, provide for: organization and operation of schools, democratic management, evaluation process, organization and development of educa-

${ }^{3}$ Recently, we see some initiatives in the form of bulletins on International Women's Day, sent to public schools with activities to be developed by the teachers by the Union of Teachers - APEOESP, which currently has a Collective Gender. 
tion, technical and administrative organization and organization of school life. Show that it is up to the school management, "to ensure the association of the joint parent-teacher with the school board and create conditions for organization of students in student government." With regard to liability with/the students/as, in accordance to the Estatuto da Criança e do Adolescente (Statute of Children and Adolescents), to provide "information to parents or guardians about attendance and student performance, as well as on the implementation of the educational proposal". In addition, it points to the school's responsibility for the child's protection and/teen making "communication to the Council of Guardianship of cases of abuse involving students, as well as cases of truancy and repeated absences, [...], "understanding them/them as subjects of rights.

In Chapter VII, Article 69 of the NRB shows that all pupils and students "will ensure free access to information necessary for its education, its development as a person, his preparation for the exercise of citizenship and his qualification for world of work ". It does not specify how it will happen this training but it is implied that in addition to the acquisition of historically accumulated knowledge, the school must provide the knowledge rights, promote in the daily democratic interpersonal relationships and activities, together with the study, allow the preparation for citizenship, or should experience citizenship exercise situations. In this sense, participation in collegiate bodies and in schools, such as the Student Government, it is important for the formation of youngers.

\section{Conclusion}

As is possible observed, the effective participation of the subjects of the school community, therefore, formation for citizenship must start at school and, thus, all its processes, centrally of its political-pedagogical project in all its stages they have to be systematized to enable such participation, particularly as regards the participation of pupils, subject formation in the various school levels, as in their collegiates.

Although the possibility of creation of these colleges in Brazilian schools dates back to the 1980s, as the Unions Research shows that there is still prejudice against the role of the students, restrictions on their effective participation, it is believed that the Union is only for defense. In the early days of its creation, there was also concerned about the involvement of the young people with political parties.

At the time of research in one of the public schools, that organization had a role in helping the school team and was of better use of time and space in school. There was no joint activity with the Council or the Associação de Pais e Mestres (Association of Oarents and Teachers) - APM. In this sense, there was no collective political learning, however, exercised a dialogue with the management and pedagogical coordination. There was incentive for participation occurred, however, they had no autonomy and, moreover, always attended those considered good and behaved students. Through observation of meetings, monitoring the election process for the composition of Union and interviews with its members, 
it was found that there was an interest in participating in the meetings which were moments of dialogue between all boys and girls participated. The process of the election campaign, from the preparation of the work proposal to the debate when presented to male and female students, was a time of learning democratic dialogue and reflections on the legal rules that organized the election. Although there was concern with encouraging the participation of both boys and girls, each year increasing the number of girls being that twice they took the presidency with boys in the office of vice-presidents and resistance was not observed in this regard. At the beginning of the study had a greater number of boys and, at meetings, the little girls were demonstrating, however, with the passage of time began to give their opinion and defend their ideas.

In the Educational Cooperative, although have the cooperativism as a principle to be worked into the curriculum, the administration failed to involve the students and the students to form a Union. It seems that although there is the ideal of democratic principle guiding practices in everyday life, not all the teachers promote or experience it with their students. As interviews revealed, the principles of cooperativism were not assimilated by everyone in the school and this constitutes one of the problems currently detected that school.

That group, which had not yet been able to see solidified democratic principles, already begins to glimpse another ideal of education, of private school and prepare for college entrance exams, competing with those who led them to create the cooperative. We see the reflection of this way of thinking by parents and teachers, and this was one of the factors that hindered the creation of the Union in that school, because participation in the educational process is not seen as a value to be working with children and young people.

Regarding the gender issue, we found that it was not included in the pedagogical proposal of the two schools, is not seen as a relevant issue for most of the professionals, there is a lack of knowledge in the subject. However, discussions are already undertaken in the month dedicated to the International Women's Day and the Day to Combat Violence against Women at the two schools, however, in a timely manner. We note that when the school encourages participation of students at Union, ultimately promote the role of young people of both sexes. In the two schools still seems to prevail that says Foucault (1991), the school's concern is to control the behavior of young people, establishing the order, respect for hierarchy, sometimes promoting the alienation on their own reality.

\section{References}

Aredes, A. P. J. (2002). The Instances of Participation and the Democratization of the Public School. Thesis (Doctorate in Education), Faculty of Philosophy and SciencesFFC/UNESP/Marília.

Benevides, M. V. (1994). Citizenship and Democracy. Lua Nova: Revista de Cultura e Política, 33, 5-16.

Bobbio, N. (1987). The Future of Democracy: A Defense of the Rules of the Game (2nd ed.). Rio de Janeiro: Peace and Earth.

Brabo, T. S. A. M. (2005). Citizenship of the Woman Teacher. São Paulo: Icon. 
Brabo, T. S. A. M. (2003). Gender and Local Power: 2000 Municipal Elections in Marília (SP). PhD Thesis, FFLCH-USP.

Brazil (1997). Secretariat of Basic Education. National Curricular Parameters. Brasília: MEC/SEF.

SEE-ATPCE, SP (1987). Decree n. 25,469, July 7, 1986. In Debate-Women and Education: The Role of Women in Society.

Foucault, M. (1991). Watch and Punish. Rio de Janeiro: Voices.

São Paulo (1998). Secretary of State for Education. Basic Rules for State Schools. São Paulo: SE.

São Paulo (1992). Statute of the Child and Adolescent, Law no 8.069, dated July 13, 1990, São Paulo (SP).

Oliveira, I. B. (2001). Democracy in the Daily Life of the School. Rio de Janeiro: DP \& A SEPE.

Paoli, M. C. (1995). Social Movements in Brazil: In Search of a Political Statute. In M. Hellmann (Ed.), Social Movements and Democracy in Brazil. São Paulo: Marco Zero, ILDES FES, LABOR.

Reston, J. (1990). The Municipality: An Institution of All of Us. In Transitions: Women in Democratic Processes. Women's Editions.

Sales, T. (1994). Roots of Social Inequality in Brazilian Political Culture. Revista Brasileira de Ciências Sociais, 9, 27-51.

Vasconcelos, C. S. (1999). Planning: Teaching-Learning Project and Political-Pedagogical Project (5th ed.). São Paulo: Freedom.

Submit or recommend next manuscript to SCIRP and we will provide best service for you:

Accepting pre-submission inquiries through Email, Facebook, LinkedIn, Twitter, etc. A wide selection of journals (inclusive of 9 subjects, more than 200 journals)

Providing 24-hour high-quality service

User-friendly online submission system

Fair and swift peer-review system

Efficient typesetting and proofreading procedure

Display of the result of downloads and visits, as well as the number of cited articles

Maximum dissemination of your research work

Submit your manuscript at: http://papersubmission.scirp.org/

Or contact ce@scirp.org 